\title{
Digestion and microbial protein synthesis in sheep as affected by exogenous fibrolytic enzymes
}

\author{
W.F.J. van de Vyver $^{\#}$ \& B.A. Useni \\ Department of Animal Sciences, Stellenbosch University, Private Bag X1, Matieland 7602, South Africa.
}

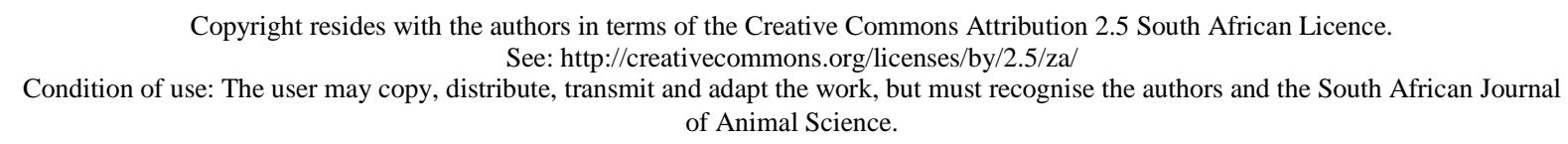

\begin{abstract}
The aim of the study was to determine the effect of an exogenous fibrolytic enzyme (EFE) on the ruminal disappearance of dry matter (DM), neutral detergent fibre (NDF), crude protein (CP) and on the microbial protein synthesis (MPS) in sheep of a milled substrate consisting of a $50: 50$ mixture of lucerne hay (LH) and wheat straw (WS). Four cannulated Döhne-Merino sheep were randomly assigned to two groups in a 2 x 2 cross-over experiment. Additional to the in situ study, the effects of an exogenous fibrolytic enzyme (EFE) on the in vitro gas production (GP) and ANKOM digestion systems on the mixture of milled LH and WS were determined. The substrate was pre-treated with distilled water (control) or EFE (treatment) 12 hours prior to incubation to allow interaction between the substrate and enzyme. Adding EFE significantly improved the in vitro cumulative gas production (GP), but it did not affect the in vitro MPS measured as purine derivates of the GP residues. The enzyme significantly increased the in vitro DM and NDF disappearances after 36 hours. However, the in situ disappearances of DM, NDF and CP of the roughage mixture were not affected by the EFE. Further, the in situ MPS was increased significantly with the EFE treatment of the mixed substrate. It is concluded that the improved ruminal digestion of DM, NDF and $\mathrm{CP}$ is not only due to direct enzyme hydrolysis, but also due to the improvement of MPS.
\end{abstract}

Keywords: Fibre digestion, in vitro and in situ digestion, ruminants

\# Corresponding author: wvdv@sun.ac.za

\section{Introduction}

Ruminant production systems are based on the utilization of forages, with fibrous material being important for salivation, rumen buffering and efficient production of rumen end products. However, less than $65 \%$ of the fibrous plant cell walls are efficiently digested in the total digestive tract of ruminants (Van Soest, 1994). With $40 \%-70 \%$ of the forage DM consisting of cell walls, it would be important to improve ruminal fibre digestion. Forage digestibility has been improved by several biotechnological products, i.e. ionophores, direct fed microbial products and a number of enzymes. In the past 10 to 15 years, the use of EFE as feed additives has shown promise at hydrolyzing plant cell walls (Beauchemin et al., 2004). However, their biological response in ruminant systems is difficult to predict because of inconsistent results (Beauchemin et al., 2003). In an effort to improve the nutritive value of ruminant feedstuffs, a novel EFE, produced from a fungal strain isolated from soil in South Africa and cultivated on wheat straw, was evaluated. The EFE was characterised with xylanase as the major fibrolytic activity (Cruywagen \& Van Zyl, 2008) and evaluated in a ruminant system using in vitro and in situ techniques. The aim of the study was to determine the EFE effect on the DM, CP and NDF digestion of a mixture of lucerne hay and wheat straw (50: 50) to improve MPS. 


\section{Materials and Methods}

The protocol of the study was approved by the Animal Care and Use Committee of Stellenbosch University (SU ACUC, ethical clearance number: 2006B03005). Four cannulated Döhne-Merino sheep were randomly assigned into two groups in a 2 x 2 cross-over experiment. The study was conducted as two main studies: 1) in situ digestibility and 2) in vitro digestibility based on the in vitro gas production (GP) and in vitro digestibility (ANKOM Technologies, Fairport, NY, USA) of the pre-treated substrate. The gas production system used was based on the Reading Pressure Technique (RPT) described by Theodorou et al. (1994). Each animal received a basal diet ad libitum, supplemented in the morning with $300 \mathrm{~g} /$ day of a concentrate providing $880 \mathrm{~g} \mathrm{DM} / \mathrm{kg}$ feed, 10, 25, 1.5 and 0.2\% CP, NDF, calcium (Ca) and phosphorus (P) per kg DM, respectively. The basal diet consisted of $298.5 \mathrm{~g} \mathrm{LH} / \mathrm{kg}, 298.5 \mathrm{~g} \mathrm{WS} / \mathrm{kg}, 149.2 \mathrm{~g}$ corn starch $/ \mathrm{kg}$, $238.8 \mathrm{~g}$ molasses meal $/ \mathrm{kg}$ and $15 \mathrm{~g} / \mathrm{kg}$ of a trace mineral and vitamin premix, to contain $830.3 \mathrm{~g} \mathrm{DM} / \mathrm{kg}, 75.5$ $\mathrm{g} \mathrm{CP} / \mathrm{kg}$ DM and $361.5 \mathrm{~g} \mathrm{NDF} / \mathrm{kg}$ DM. The basal diet and water were offered ad libitum daily. Treatments of the milled substrate (a $50: 50$ mixture of LH and WS) consisted of a control (distilled water only) and EFE, a South African fungal enzyme cultivated on wheat straw and developed at the Department of Microbiology at Stellenbosch University. The enzyme was used as either a lyophilised enzyme concentrate ( $0.5 \mathrm{~g}$ enzyme powder $+68 \mathrm{~mL}$ of distilled $\mathrm{H}_{2} 0$ ) or fresh supernatant (one $\mathrm{mL}$ of enzyme supernatant $+200 \mathrm{~mL}$ of distilled $\mathrm{H}_{2} 0$ ) to supply the exact same amount of enzyme activity. The EFE was analyzed to contain cellulases, xylanases and mannanases, with xylanase being the major fibrolytic activity (Cruywagen \& Van Zyl, 2008). The EFE was applied 12 hours prior to the in vitro or in situ incubation as pre-treatment of the milled and sieved substrate, to allow for an enzyme-substrate interaction time as recommended by Beauchemin et al. (2003). The application of treatments was at a ratio of one $\mathrm{mL}$ of the EFE dilution or distilled water to $0.5 \mathrm{~g}$ substrate for the in vitro studies. Similarly, the standard diet was treated 12 hours before feeding at a daily level of $5 \mathrm{~mL} / \mathrm{kg}$ feed to provide either no enzyme (Control: distilled water) or EFE treatment for the in situ study.

To ensure good homogeneity, $5 \mathrm{~mL}$ enzyme concentrate or distilled water was added to $100 \mathrm{~mL}$ of distilled water before being sprayed on one kg of the basal diet. As described by Useni (2011), a series of in situ and in vitro incubations over 48 hours were simultaneously conducted following a 10 day adaptation period to the basal diet. While the in vitro nylon bag technique was executed accordingly to the Daisy ${ }^{\text {II }}$ procedure as described by the manufacturer (Ankom ${ }^{\circledR}$ Technology Corp., Fairport, NY, USA), the in vitro GP and the in situ digestibility were conducted according to Goosen (2005) (based on the system described by Theodorou et al. (1994)) and Vanzant et al. (1998), respectively. A buffered media solution (Goering \& Van Soest, 1970) was used for the in vitro incubations while the rumen liquor acquired was collected at 06h00 from the rumen cannulated sheep adapted to the basal diet. The DM, CP, NDF and purine derivates of original sample and residues were measured according to chemical analyses as described by the AOAC (1995). Data was subjected to a two-way repeated measures of analysis of variance (ANOVA) and treatment means were compared with a Bonferroni test to determine significant differences, using SAS (2006 ). Significance was declared at $P<0.05$.

\section{Results and Discussion}

The effect of EFE on GP is indicated in Figure 1(a) as the cumulative gas produced over a $48 \mathrm{~h}$ incubation period. At the end of the $48 \mathrm{~h}$ incubation period, MPS was measured on the residual material as purine derivates of the mixed substrate (Figure 1(b)). Pre-treatment of a mixed substrate with EFE resulted in an improved cumulative GP $(P<0.01)$ but had no effect $(P>0.05)$ on the MPS (measured as purine derivates) with EFE treatment was observed (Figure 1).

Additionally, the in vitro disappearance of DM and NDF were improved at 36 hours of incubation due to the enzyme treatment, by respectively $6.28 \%(P=0.03)$ and $2.85 \%(P=0.05)$. Similar to these findings, Goosen (2005) reported a positive EFE effect on the cumulative GP and the in vitro DM and NDF degradation of wheat straw. Beauchemin et al. (2003) reported that the addition of EFE to dry feedstuffs before feeding enhances the binding of EFE with the substrate, which can improve the resistance of EFE to proteolysis and prolong their residence in the rumen. This can result in an enhancement of colonization and digestion of slowly degradable plant cell wall fractions by ruminal micro-organisms (Feng et al., 1996). 

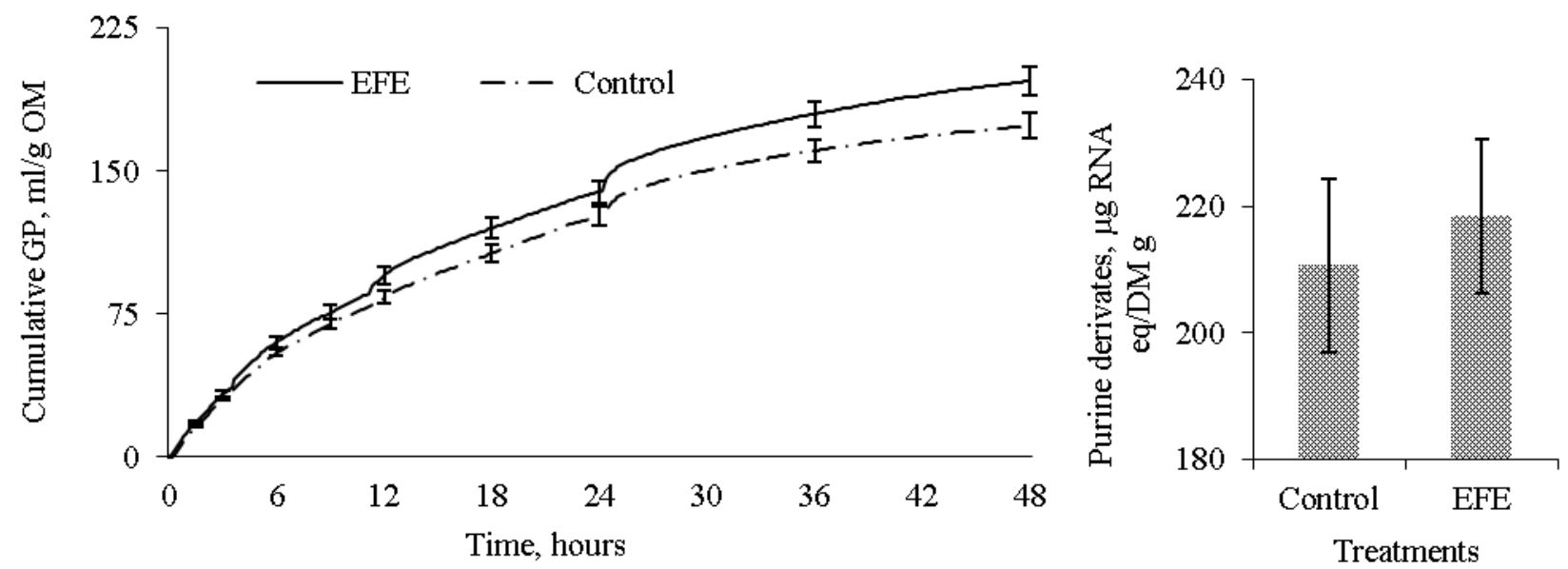

(a)

(b)

Figure 1 The cumulative gas production (GP) (mL/g OM) of the EFE treated or control mixed substrate (a) and the microbial protein synthesis (MPS) measured as purine derivates (RNA equivalent in $\mu \mathrm{g} / \mathrm{DM} \mathrm{g}$ ) on residues of GP after 48 hours (b). Error bars indicate the standard error of the mean.

The in situ disappearances of DM, NDF and CP did not differ $(P>0.05)$ between the EFE treated substrate and the control (Figure 2). This may be due to the small number of cannulated sheep $(n=4)$ used in the study and the relatively high coefficients of variation associated with measuring ruminal digestion. The in situ MPS, measured as purine derivates, was, however, increased with EFE addition to the substrate ( $P$ $<0.01$ ) (Figure 3). Similarly, Nsereko et al. (2002) found that EFE indirectly increased the attachment and the number of cellobiose- and glucose-utilizing bacteria in the rumen. Giraldo et al. (2008) reported that treating high-forage diets with EFE increased fibrolytic activity and stimulated the in vitro numbers of micro-organisms. Likewise, Yang et al. (1999) found that EFE significantly improved the supply of metabolizable protein to the small intestine, measured as ${ }^{15} \mathrm{~N}$. In two other studies evaluating this enzyme at a similar dose, it improved $(P<0.05)$ body weight gains and feed conversion efficiency when fattening lambs on forage based-diets (Cruywagen \& Goosen, 2004; Cruywagen \& Van Zyl, 2008). It is suggested that the EFE increased the hydrolytic capacity in the rumen probably improving fibre digestibility.

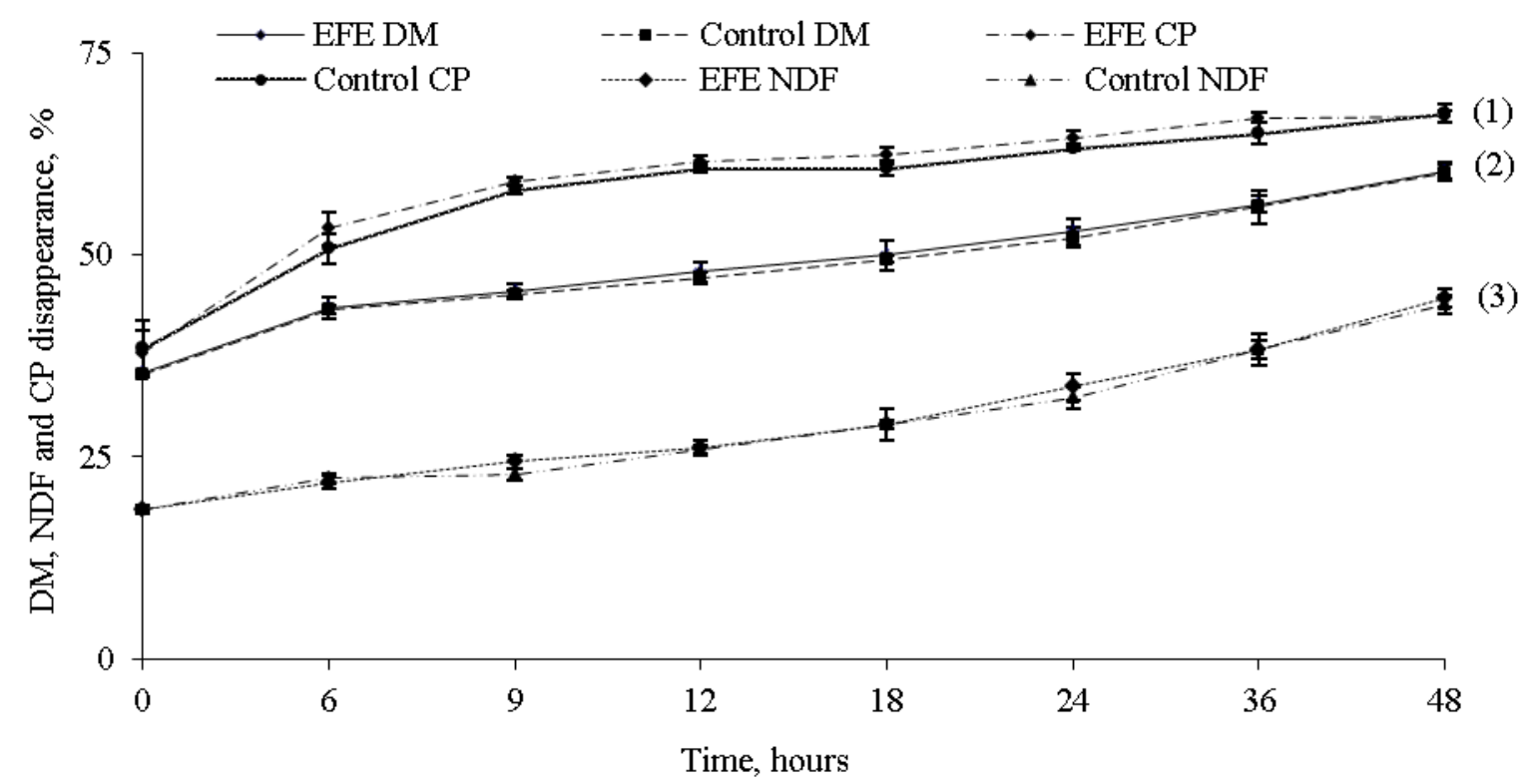

Figure 2 The effects of an exogenous fibrolytic enzyme (EFE) on in situ disappearances of (1) CP, (2) DM and (3) NDF of the mixed substrate. Error bars indicate the standard errors of mean. 


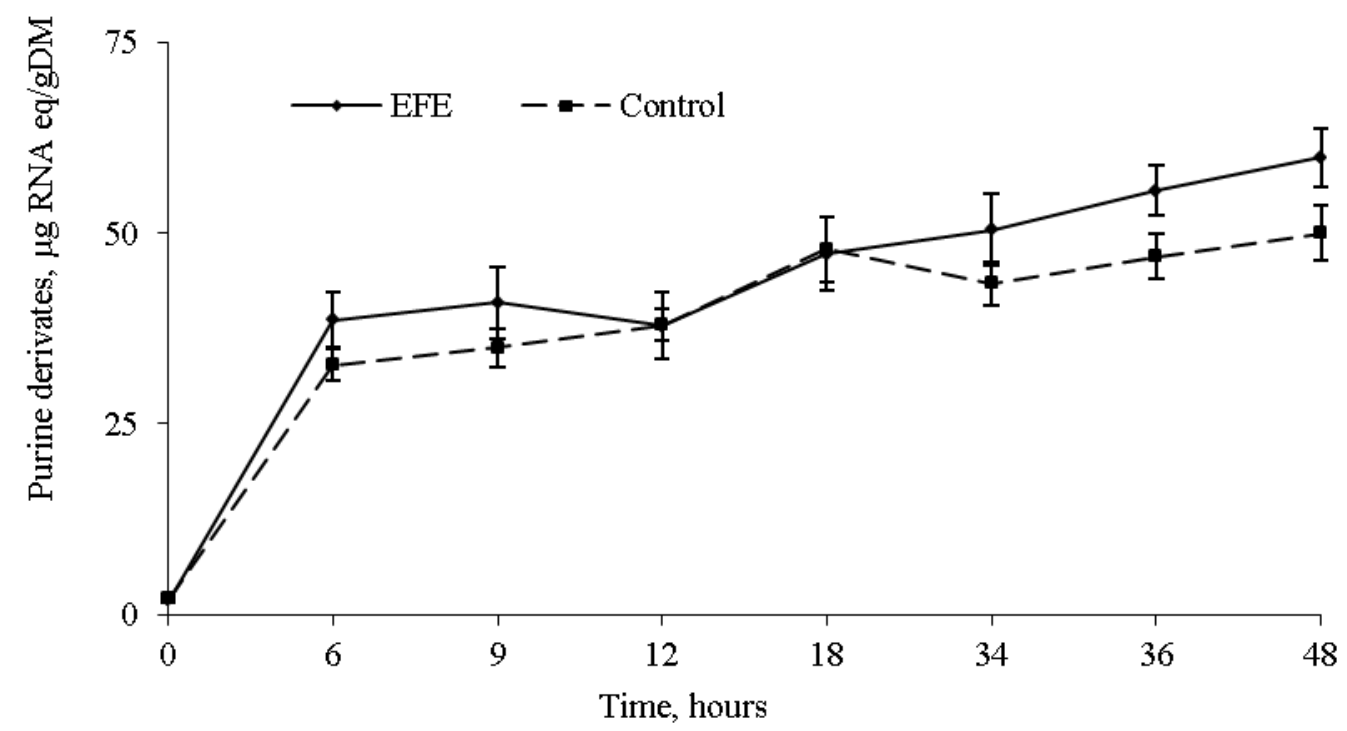

Figure 3 The effects of an exogenous fibrolytic enzyme (EFE) on the microbial protein synthesis (MPS) measured as purine derivates (RNA equivalent in $\mu \mathrm{g} / \mathrm{g} \mathrm{DM}$ ) on residues of in situ nylon bag digestion. Error bars indicate the standard errors of mean.

There are several possible explanations for the increased MPS observed in the in situ study. One such explanation is the direct effect of the EFE that can randomly release reducing sugars and possibly make more nutrients available for utilization by the microorganisms (McAllister et al., 2001), arising from the partial solubilisation of cell wall components (Krause et al., 1998). As stated by Beauchemin et al. (2004), the presence of soluble sugars would supply sufficient additional available carbohydrates to shorten the lag time needed for microbial colonization and also enhance the rapid microbial attachment and growth. The EFE effect on nutrient release can also favour an increased production of the glycocalyx, which is produced by bacteria, allowing adhesion between bacteria and between bacteria and substrate. Bala et al. (2009) observed an increase in milk yield of lactating goats. The authors ascribed this to the improvement of the energy availability and the utilization of microbial digestible protein, estimated as purine derivatives and creatinine excreted in urine (Bala et al., 2009). These authors speculated that the EFE was able to free the trapped nutrients in the cell wall networks of roughages. The increased availability of nutrients to micro-organisms in the rumen was reported by Chakeredza et al. (2002) to improve the yield of fermentative end-products due to a change in the ratio of micro-organism biomass to the digestible energy in the rumen.

\section{Conclusion}

Research on EFE in ruminant diets reports on improvements of forage utilization, production efficiency and reduced nutrient excretion. A South African EFE, produced from a fungal strain isolated from SA soil, shows potential to enhance fibre digestion of forage based-diets fed to ruminants. The current study indicated an increased in vitro GP, coupled with increased in vitro DM and NDF disappearances at $36 \mathrm{~h}$ of digestion. Although in vitro digestibility was increased, results did not indicate a significant increase in MPS measured on the residual matter after in vitro digestion. Microbial protein synthesis (MPS) was however increased on the residual matter after in sacco digestion, especially after $24 \mathrm{~h}$ digestion periods and up to $48 \mathrm{~h}$. The improvement of feed digestion in this study was attributed to enhanced in situ MPS, possibly due to the EFE treatment resulting in an increased availability of nutrients for microbial growth. The net effect of EFE on feed digestion is a combined result of direct hydrolysis of substrate, increased microbial attachment, stimulation of the rumen microbial population and synergistic effects with hydrolases of ruminal micro-organisms. 


\section{Acknowledgments}

The authors express gratitude to the Department of Microbiology of Stellenbosch University for the supply of the EFE, to C.W. Cruywagen for professional support, to the Centre of Statistics of Stellenbosch University and G.F. Jordan for assistance with the statistical analysis of the data.

\section{References}

AOAC, 1995. Official Methods of Analysis, 16th ed. Association of Official Analytical Chemists, Washington, D.C., USA.

Bala, P., Malik, R. \& Srinivas, B., 2009. Effect of fortifying concentrate supplement with fibrolytic enzymes on nutrient utilization, milk yield and composition in lactating goats. J. Anim. Sci. 80, 265-272.

Beauchemin, K.A., Colombatto, D., Morgavi, D.P. \& Yang, W.Z., 2003. Use of exogenous fibrolytic enzymes to improve feed utilization by ruminants. J. Anim. Sci. 81 (E. Suppl. 2), E37-E47.

Beauchemin, K.A., Colombatto, D., Morgavi, D.P., Yang, W.Z. \& Rode, L.M., 2004. Mode of action of exogenous cell wall degrading enzymes for ruminants. Can. J. Anim. Sci. 84, 13-22.

Chakeredza, S., Meulen, U. \& Ndlovu, L.R., 2002. Ruminal fermentation kinetics in ewes offered a maize stover basal diet supplemented with cowpea hay, groundnut hay, cotton seed meal or maize meal. Trop. Anim. Health Prod. 34, 215-230.

Cruywagen, C.W. \& Goosen, L., 2004. Effect of an exogenous fibrolytic enzyme on growth rate, feed intake and feed conversion ratio in growing lambs. S. Afr. J. Anim. Sci. 34 (Suppl. 2), 71-73.

Cruywagen, C.W. \& Van Zyl, W.H., 2008. Effects of a fungal enzyme cocktail treatment of high and low forage diets on lamb growth. Anim. Feed Sci. Technol. 145, 151-158.

Feng, P., Hunt, C.W., Pritchard, G.T. \& Julien, W.E., 1996. Effect of enzyme preparations on in situ and in vitro degradation and in vivo digestive characteristics of mature cool-season grass forage in beef steers. J. Anim. Sci. 74, 1349-1357.

Giraldo, L.A., Tejido, M.L., Ranilla, M.J., Ramos, S. \& Carro, M.D., 2008. Influence of direct-fed fibrolytic exogenous enzymes on diet digestibility and ruminal activity in sheep fed a grass hay-based diet. J. Anim. Sci. 86, 1617-1623.

Goering H.K. \& Van Soest, P.J., 1970. Forages Fibre Analysis. (Aparatus, reagents, Procedures and some applications) USDA Agricultural Handbook no. 379, ARS-USDA, Washington, D.C., USA. pp. 1-20.

Goosen, L., 2005. The effect of an exogenous fibrolytic enzyme on forage digestibility parameters. MSc (Agric.) thesis, Stellenbosch University, Stellenbosch, South Africa.

Krause, M., Beauchemin, K.A., Rode, L.M., Farr, B.I. \& Nørgaard, P., 1998. Fibrolytic enzyme treatment of barley grain and source of forage in high-grain diets fed to growing cattle. J. Anim. Sci. 96, 1010-1015.

McAllister, T.A., Hristov, A.N., Beauchemin, K.A., Rode, L.M. \& Cheng, K-J., 2001. Enzymes in ruminant diets. In: Enzymes in Farm Animal Nutrition. Eds. Bedford, M.R. \& Partridge, G.G., CAB Inter. pp. 273-298.

Nsereko, V.L., Beauchemin, K.A., Morgavi, D.P., Rode, L.M., Furtado, A.F., McAllister, T.A., Iwaasa, E.A., Yang, W.Z. \& Yang, Y., 2002. Effect of a fibrolytic enzyme preparation from Trichoderma longibrachiatum on the rumen population of dairy cows. Can. J. Microbiol. 48, 14-20.

SAS, 2006. Statistical Analysis Systems (Enterprise guide 4). SAS ${ }^{\circledR}$ Institute Inc., Cary, N.C., USA.

Theodorou, M.K., Williams, B.A., Dhanoa, M.S., McAllen, A.B. \& France, J., 1994. A simple gas production method using pressure transducers to determine the fermentation kinetics of ruminant feed. Anim. Feed Sci. Technol. 48, 185-197.

Useni, B.A., 2011. Effect of exogenous fibrolytic enzymes on fibre and protein digestion in ruminant animals. MSc (Agric.) thesis, Stellenbosch University, Stellenbosch, South Africa.

Vanzant, E.S., Cochran, R.C. \& Titgemeyer, E.C., 1998. Standardization of in situ techniques for ruminant feedstuff evaluation. J. Anim. Sci. 76, 2717-2729.

Van Soest, P.J., 1994. Nutritional Ecology of the Ruminant. $2^{\text {nd }}$ ed. Cornell University Press, Ithaca, NY, USA.

Yang, W.Z., Beauchemin, K.A. \& Rode, L.M. 1999. Effects of the enzyme feed additive on the extent of digestion and milk production of lactating dairy cows. J. Dairy Sci. 82, 391-403. 